\title{
STATESMEN AND POLITICIANS IN EARLY IOWA
}

\author{
By The Rev. Charles E. SNyder, Litt. D.
}

A hundred years is but a little time in the course of human affairs. When one tries to lay hold on the eight or ten thousand years since the dawn of civilization on the banks of the Nile; when one tries to imagine the flight of the years since the first rude chisels imprinted cuneiform characters on tiles made of the mud of the Euphrates and the Tigris; when one feels the mystery of time as he stands among the ruins of temples and capitals that mark "The glory that was Greece and the grandeur that was Rome," the single century of Iowa history seems wholly insignificant. It is but the wink of an eye in those infinite processes in which a thousand years are but as a day when it is past. Yet, that century has seen four generations of men and of women lay hold upon the making of history. The great grandchildren live and labor in the cities their great grandparents founded; that is, where the younger generation has stayed near the pioneer homesteads. In our restless moving population, that has not often occurred. There are not many who remember even the names of the founders. Names that were generally known a hundred years ago, as familiarly as we know those of our friends whom we meet every day or as those of whom we read in the public news every day, are forgotten. Only a hundred years, and the dusk of night has dimmed them from common knowledge. The men who laid the foundation stones are forgotten men.

Our approaching centenary as a state serves to bring some of those names out of the darkness for a while. It introduces to the present generation that grim and stern former governor of Ohio, with the Jacksonian face and hair and the Jacksonian politics, Robert Lucas, who ac- 
cepted Van Buren's invitation to travel out to the frontiers, to become the first governor of the new Territory of Iowa. After his appointive term expired he stayed in Iowa to continue as a leader in public opinion and in party affairs. It resurrects those two first statesmen of the new state, who became the first United States senators from Iowa, Augustus Caesar Dodge and George W. Jones. Both of them products of Vincennes, Indiana; both of them raised to manhood in Ste. Genevieve, Missouri; both of them prospecting in the lead regions of Wisconsin; they both followed the territory becoming Iowa's first United States senators; and each of them received appointment to a foreign ministry when political reversal in 1854 turned their party out of power in Iowa. Jones went to New Granada, now the Republic of Columbia, in South America. Dodge went to Spain. Finally both came back to Iowa to spend their last years and to die honored and held in high esteem after the noise and the confusion of political hysteria had stormed itself out. It calls forth from the obscurity of a hundred years numerous other men who were the results of creative processes in older parts of the country and who now came to the frontiers to create anew out of the cultures from which they were born. Some of them had parts in the shaping of the events that led from territorial status to statehood and in the process of creating the political story of the new state.

The first territorial legislature which was elected in September, 1838, and which met in Burlington in November, had in its membership some men who were going further than that legislature, and who were to be prominent in the political life of the new state. It was notable, first, because it was made up so generally of young men. Among the thirteen members of the council, there were only three who were forty or more, Brown of Lee, Inghram of Des Moines, and Keith of Van Buren. Jesse B. Brown was made the president. He was a Kentuckian by birth, forty years old, six feet seven inches tall, weighed 
a hundred and ninety pounds-not a great weight for that height.' He had commanded a company in the Blackhawk war, and later was a captain in the regular army. He resigned from the army in 1837 and located at Fort Madison as a merchant. He was so eminently fair and generous as a presiding officer that his prestige grew as the session advanced. He continued to serve in successive territorial legislatures, and was the Speaker of the House in the First General Assembly of the state, in 1846. He was defeated for congress in 1847 by William Thompson, and years later he returned to Kentucky where he died in 1864.

Also in the council was Stephen Hempstead, of Dubuque, aged twenty-six. He was one of the earliest lawyers in Dubuque. He was born in Connecticut in 1812; came out to the vicinity of St. Louis in 1828. In 1830 he went to Galena, and there got mixed up in the Blackhawk war. He then went to Illinois College, studied law with a relative in Galena, Charles T. Hempstead. In 1836 he located in Dubuque. He was elected to the council in 1838, where he became chairman of the Judiciary committee; and he continued in the council in the Second, Seventh and Eighth Territorial Legislatures. He also served in the Constitutional Conventions of 1844 and of 1846. He was one of the Commissioners appointed to revise the code appointed in 1848 . In 1850 he became the second governor of the state, which office he held for four years, the term prescribed by the Constitution of 1846 . In 1854 he was defeated for congress by James Thorington of Davenport. That was the year that saw the eclipse of the Democratic party in Iowa; Grimes was elected governor, the legislature became Whig, and the slavery question was doing its work. Governor Hempstead, in 1855 , was elected county judge of Dubuque county and held that office twelve years. He had a good deal to do with the shaping of the affairs of the territory and of the beginnings of the state-a generous, pure hearted, 
able gentleman, handsome, chivalrous, and a delightful conversationalist.

The house elected as its speaker W. H. Wallace of Henry county, another young man, twenty-seven years old. He was born in Ohio, educated in the common schools of Indiana, studied law there, came to Iowa in 1837; for a time he was receiver of the land office in Fairfield, but his home was in Mount Pleasant. His brother, Benjamin F. Wallace, also lived in Mount Pleasant; he was one of the candidates for delegate to congress in 1838. William Henry is spoken of by one of his contemporaries as "impressive in manner, person, and voice, he was a model officer." He served in five sessions of the territorial legislature, four in the council. He was possessed of the pioneer spirit, and in $\mathbf{1 8 5 3}$ he migrated to Washington territory, was elected to the territorial council, and was appointed governor of Washington Territory by Lincoln in 1861. He refused the appointment, however, as he had been elected delegate to congress from that territory. He served one term, and then was appointed first governor of the Territory of Idaho, in 1863. Idaho soon sent him to Washington as delegate to congress where he served one term, thus establishing the unique record of representing one territory in the Thirty-seventh Congress and another in the Thirty-eighth. He died in Washington Territory, in 1879.

\section{Capital Moved to Nonexistent Town}

In the House, out of twenty-six members only five were forty or more. The oldest was Thomas Cox of Jackson, and there was a picturesque figure. He was only fiftyone, but that was much older in those days than it is now, standing over six feet tall, weighing two hundred and fifty pounds, he carried weight both of appearance and of leadership of the frontier kind. Athletic, strong of limb, an excellent horseman, he was the stuff of which leaders are made. He had lived in Illinois, was a member 
of the First Senate in that state. Of course, he got in the Blackhawk fracas; most everybody in Illinois did, but not everybody gloriously. He came to Iowa and settled in Jackson county. He was the father of the act in the First Territorial legislature which established the capital in a non-existent town which he named Iowa City.

When it came time to run for the next term he found it necessary to be absent from home for a time, and he left his campaign in the hands of his friend, W. W. Brown. When he got back he found that Brown had come out as a candidate himself. Cox turned in and beat him. Brown later proved to be the leader of the banditti who were ravaging homes and stables, horse thieves and counterfeiters, up and down the river. Cox organized the posse in January, 1840, that smashed the gang at Bellevue, led by Brown, who up to that time had covered his tracks. Brown was shot in the melee. The volunteer jury determined by a vote of differently colored beans that those captured should be horsewhipped and driven out rather than hanged. On July 4, 1845, some remnants of the gang shot Col. George Davenport at his home in Rock Island. The names of those bandits were John and Aaron Long and Granville Young.

Cox served five terms in the territorial legislature, but he was not permitted to witness the birth of the state. He died in November, 1844.

From Muscatine county there was Serranus C. Hastings, twenty-four years old. He was born in Watertown, N. Y., in 1813, to a boyhood of small-town poverty, and he got an education by extraordinary effort, finally being graduated from Hamilton college. He came to Indiana, studied law, then moved to Iowa, settling first in Burlington, in 1837, but soon coming up the river to Bloomington, the present Muscatine. He served in all of the territorial legislatures, except the Fifth and Sixth. When Iowa became a state in 1846 he was one of the two congressmen elected from the new state. In 1848, he was appointed 
chief justice of the Supreme Court of Iowa; but in 1849 he succumbed to the California fever, and started west. He soon assumed leadership, became chief justice of the Supreme Court of California and in 1851 was elected attorney-general. He practiced law after that and became wealthy in land speculation. He established and endowed the law school of the University of California, known as the Hastings Law School. He died in 1893 in San Francisco.

\section{Advent of a Notable Figure}

The youngest man in the House was destined for big affairs. His name was James W. Grimes, twenty-two years old ; and probably besides being the youngest, he was the most vocal and the most active. Those young fellows were feeling their oats, and they could see no reason why age, particularly as personified by Governor Lucas, who was fifty-seven, weather bitten and politically hardened, should be in their way. Grimes was born in New Hampshire in 1816, in the same township, Hillsborough, as Franklin Pierce; and was graduated from Dartmouth in 1836. He read law a few weeks, was admitted to the bar and migrated to "The Blackhawk Purchase," to Burlington. He was born to be seen and to be heard, and fortunately he developed the ability and the character to justify all of that. In the house he was quick in debate and ready for the fray. They made him chairman of the Judiciary committee, so he and Hastings over in the council, had a good deal to do with early legislation, and much of it shows its youthful parentage. Grimes was to become a powerful figure in Iowa. He was frankly and outspokenly a Free Soiler, in the early fifties when the Whig party was rent and torn with all kinds of factions split apart on the slavery issue. The Democrats were troubled by the impact of the same issue, and their hold in the state cracked against the ardent campaign Grimes put up as the Whig candidate for Governor in 1854 which he had 
won by his forthright position. He served the four year term and then was twice elected to the senate of the United States, where he served from 1859 to 1869 . He was one of the organizers of the Republican party in this state; but when that party ran amok in 1868 under the leadership of the most determined band of radicals that the United States has known, Wade, Chandler, Stephens, and the rest, Grimes refused to sell his honor. He was one of the seven "Regulars" among the Republicans who voted "no" in the impeachment trial of Andrew Johnson. The strain, and the anxiety over the piratical policies of his colleagues, broke him. As the trial approached its end, he was stricken with paralysis; and on the sixteenth day of May, 1868, Grimes was carried into the senate chamber to cast his vote for acquittal. Six other "Regulars" voted with him; it needed only one more vote to convict. Those seven men, Fessenden of Maine, who was Grimes' closest friend, Fowler of Tennessee, Henderson of Missouri, Ross of Kansas, Trumbull of Illinois, Van Winkle of West Virginia, and Grimes of Iowa, saved the nation from the closest threat of despotism it has ever faced. His health did not return. In 1871 he resigned from the senate, came back to Burlington to rest. On February 7,1872 , his tired heart stopped beating, and a brave man died. He was only fifty-five.

For legislative purposes, Scott and Clinton counties were united into one district. The member of the Council was Jonathan W. Parker, a native of Vermont, twentyeight years old. He had come prospecting out into the west, as a young lawyer, and coming up the river on a boat in the early winter of 1836-37 the boat froze in at Davenport. He liked the little town so well that he stayed, and, his father and other members of his family followed. He became the third mayor of Davenport; he delivered the first Fourth of July oration here, in 1838 . He was a botanist of ability. In 1844 he left Davenport, studied medicine and began the practice of that profession in Cin- 
cinnati, where he died of cholera in 1850 . He was elected to the first four territorial Councils and was president of that body in the second legislature. His father, also Jonathan Parker, was a civil engineer who in 1850 ran the first line of the Rock Island railroad from Peru to Rock Island. A sister became the wife of James Thorington, who was destined to importance in Davenport and the state. Thorington held many local offices, and in 1854 he beat Stephen Hempstead, then retiring from the new state's gubernatorial chair, for congress. Thorington's home stood on the present site of the Public Library in Devenport, where he ran a private school for some years.

The representatives in the lower house were Laurel Summers and J. A. Burchard, Jr. Summers was an Ohioan by birth. His parents moved to Indiana, where the young man learned the trade of brick mason. He came to Scott county in 1837, and settled at LeClaire, where he married one of the Parkhurst girls. He tried farming and ranching at first, on a scale too big to run successfully. Then he returned to his trade. He took to politics pretty readily; was elected to the House for three successive terms and to the Council for the Seventh and Eighth sessions of the territorial legislatures. The old newspaper files speak of him frequently in Democratic affairs. He served in the House of Representatives in the Third General Assembly of the State. In 1853 he became United States marshal and served until 1861.

J. A. Burchard, Jr., got his seat only after a contest. He was voted for both with, and without the "Jr." on the name. As his father had the same name some votes were counted for him, and the certificate of election was given to Samuel A. Murray of Camanche on the basis of such returns. Burchard contested, and was seated. He came from an old Massachusetts family, dating back to Plymouth Rock. The family came to Scott county in 1836, stopping first in Buffalo and then moving on to Pleasant Valley. He served only one term in the legislature. In 
1837 he became postmaster at Pleasant Valley, and served until 1856. He also held different county offices. He died in 1871.

\section{Elected But Killed Before Serving}

There was one man elected to the legislature who did not take his seat. Cyrus Jacobs of Burlington very thoroughly disliked David Rorer of the same city. Rorer was a candidate for territorial delegate to congress in 1838, and Jacobs published bitter and slanderous statements in the press. After the election in which Rorer was beaten, he met Jacobs on the street and a wordy altercation ensued. Jacobs added the force of a heavy cane to the argument and Rorer resorted to a pistol. Jacobs was killed, and Rorer in an agony of regret vowed he would never run for office again.

This man Rorer merits more than brief mention. He was a Virginian, born in 1806. Recently admitted to the bar, he migrated to Little Rock, Arkansas, in 1826, where he remained ten years. Though a Virginian, and an owner of slaves, who he afterward manumitted, he decided to move to free territory, and in 1836 he came to Burlington, where he lived until his death in 1884, one of the leading lawyers of the state during all of those years. He was a leader in all of the development of early Burlington, and in his whimsical way he was the author of the soubriquet of "Hawkeye" for Iowa. It was in 1839 that he wrote a series of humorous articles for the Fort Madison Patriot, edited by James G. Edwards. Rorer signed his letters "A Wolverine Among the Hawkeyes." The two of them got together on the "Hawkeye" proposal, to avoid such nicknames as "The Suckers" or "The Pukes" which popularly had been fastened on Illinois and on Missouri. Indeed, because of lack of barbers, shaving soap, razors, or of time, Iowans had already begun to be called "The Hairy Nation." The name of "Hawkeye," taken from an old Sauk Chief, stuck; and when Edwards' paper was moved to Burlington it eventually took the same name. 
Rorer appeared voluntarily as the attorney for Ralph the negro, whose case is mentioned in our present discussion of the Territorial Supreme Court. He was included in nearly every law case of importance in Eastern Iowa for forty years.

Reference to newspapers suggests that the first newspaper in the State was the Dubuque Visitor, established in May, 1836, by John D. King. In December, W. W. Chapman, who had moved to Dubuque from Burlington, became editor. That lasted only a few months, however, as Chapman was soon appointed United States district attorney for Wisconsin, and he formed a law partnership with Stephen H. Hempstead. When the Wisconsin legislature decided to meet in Burlington, Chapman went back there. The Iowa News was started in Dubuque in June of 1837 , but it lived only a year. The Western Adventurer and Herald was born in Montrose in June, 1837; but the next year it was absorbed by Edwards into the Patriot, and made the organ of the Whig party. In December, 1838, it was moved to Burlington. The Iowa Territorial Gazette had been established there in July 1838, by James Clarke, son-in-law of Governor Henry Dodge of Wisconsin territory and later himself governor of Iowa territory. In July, 1838, Andrew Logan, a Pennsylvanian, drove into Davenport with an old press and some type, set himself in a new log building at Main and Front streets; and on Saturday, August 4, appeared the first issue of the Iowa Sun and Davenport and Rock Island News.

It is perfectly proper to say something about these newspaper men in this resume of political leaders, for the editors were red-hot partisans in the territorial and early statehood days. When the elections came on, and in between, they let loose the vials of their lurid vocabularies without restraint. There was Verplank Van Antwerp, who came to Burlington in 1838 as receiver of the Land Office by appointment by Van Buren. In 1840 he went to the new capitol village of Iowa City and published the 
Iowa Capitol Reporter, a Democratic organ. There was a Whig paper called The Standard, then edited by one William Crum. The language that these two editors flung at each other is difficult to comprehend. The "General" as Van Antwerp was called, was a pompous, courtly, tall, slim, highly dressed chap, proud of his Knickerbocker ancestry. His editorial rival dubbed him "General Van Squirt," and "Old Pomposity." Crum referred to him in one piece of writing as "The thing which says it edits that filthy and demagogical slime of Loco-focoism, The Reporter"; Van Antwerp got even by referring to "Silly Billy, the last crum of creation."

Van Antwerp held the office of receiver of the land office in different cities. In 1846 he was nearly elected one of the first United States Senators from the new state. His wife was a cousin of Judge William Van Ness in whose office Van Buren read law and who was Aaron Burr's second on that fatal day in July, 1804, when Hamilton was shot. His daughter married George H. Williams, who later became United States senator from Oregon and attorney general in Grant's cabinet. The writer does not know what became of "the last crum of creation."

\section{BeCAME a LEADER IN IOWA}

With Governor Lucas had come from Ohio one of the most forceful, able, and versatile men in the early history of Iowa, Theodore S. Parvin. He himself said that the two greatest men in Iowa history were Charles Mason and James W. Grimes. I submit that Parvin's name must be added for a third. Parvin was a large part of the history of Iowa. He was born in New Jersey in 1817. He was graduated from Miami University in Ohio and read law for a while. In 1838 he was in Cincinnati trying to decide where to go, when by happy chance he met Robert Lucas, newly appointed governor of Iowa territory, on his way out west to assume his office. Lucas took to the young fellow of twenty-one and offered to take him along as a 
private secretary, an office not provided in the law. They reached Burlington, August, 1838. He became in quick succession territorial librarian, in which office he went back to Cincinnati to buy books; district attorney for the middle district of Iowa, which included Bloomington, where he made his home; secretary of the territorial council in 1840; clerk of the United States District court for ten years, which office overlapped that of county judge, which he also held for ten years. He was a whole regiment in the campaign to defeat the Constitution of 1844 , on the ground of the proposed boundary lines. From 1860 to 1870 he was professor of natural history in the State University. In 1852 he was elected grand master of Masons in Iowa, and in 1853 he resumed the office of grand secretary which he held until his death in 1901. Lawyer, judge, professor, collector, founder of libraries, including the Masonic library in Cedar Rapids, historian, patron of museums including that in Davenport, Parvin left the stamp of his alert, eager, active, devoted mind indelibly impressed on the new state which he helped to create.

President Van Buren designated for the supreme court of the new territory two young men who had already settled in the state and an older one who was practicing in Pennsylvania. The new chief justice was Charles Mason. One summer as I drove along a highway of long graceful sweeping curves among hills and valleys of central New York, a dozen miles or so south of Syracuse, near the little town of Pompey, we came upon a battered and weather beaten old farmhouse, standing on a hillside, alone, silent guardian of many years. Along the road was a marker reading: "The birthplace of Charles Mason, Chief Justice of the Supreme Court of Iowa Territory." Mason was born there in 1804. He was graduated from West Point in 1829, at the head of his class. The second man was one Robert $\mathrm{E}$. Lee; the thirteenth was Joseph E. Johnston; and the twenty-third was also des- 
tined for fame. His name was Jefferson Davis. Mason taught for a while at West Point, read law at Newburgh, worked for a time on the New York Post with William Cullen Bryant, and came to the Mississippi valley in 1836. He was married in Galena to Miss Angelica Gear, the aunt of John H. Gear, later an Iowa governor. In that year Mason moved to Burlington. He remained as chief justice during the territorial period; and afterwards practiced his profession in Burlington until 1882.

Thomas S. Wilson, of Dubuque, age twenty-five, was the second member of the Court. Joseph Williams of Pennsylvania was the third. A long paper could be written of their contributions to the history of the state and of their experiences in the early district courts. The state was divided into three districts and the Supreme court judges held court in the several counties of the districts, respectively, Mason in the south, Williams in the middle district (he lived at Bloomington), and Wilson in the north. The first session of a district court was held at Prairie La Porte, now in Guttenburg, September 11, 1838, by Judge Wilson. The first session in Scott county was held in October with Judge Williams presiding. It met in St. Anthony's church building; and the juries met in the little building at Main and Front streets where Andrew Logan had set up his printing press. The Supreme court held its first session at Burlington, November 26, 1838 , the only business being an order for a writ of error from Muscatine county, and the admission of twenty young lawyers to practice.

The next session, however, brought up a history making case, "In the matter of Ralph, a colored man, on habeas corpus." This was a controversy involving an issue like that of Dred Scott, some years later, but the unanimous decision of the court written by Mason gave a clear cut definition of the negro's rights drawn from his residence in free territory, and unlike the decision of Taney, held that he could not be regarded as a fugitive. 
Then came the question of "land-squatters" under an act of congress of 1807. Again Mason wrote the decision confirming the rights of the claimants, in spite of a seeming violation of the act of congress. Someone has said that, "That decision was flimsy law but it was first-class history."

\section{Iowa's First United States Senators}

I have already suggested the names of Augustus Caesar Dodge and George W. Jones, the front rank political leaders of territory and of the state in its earliest years. They became the first United States senators from Iowa, although they failed in the election in the First General Assembly which got itself so tied up in a political knot that it could elect nobody; and for nearly two years of its existence, Iowa was unrepresented in the senate. The Second General Assembly, however, had no difficulty in electing Dodge. Jones had to fight for his election, for he had fallen into a political feud with Judge Wilson of Dubuque, whom he finally beat by only two votes. Dodge sat in the senate with his father, Henry Dodge, who became one of the first senators from Wisconsin, the only instance of father and son being colleagues in that august body. Henry Dodge's younger half brother, Dr. Louis F. Linn had represented Missouri in the senate from 1833 to 1843. His help in getting the Iowa territorial bill through the Senate in $\mathbf{1 8 3 8}$ is memoralized in the name of one of our prominent counties.

In 1834 the region of "The Blackhawk Purchase" was added to the territory of Michigan for governmental purposes; and when, in 1836, Michigan became a state, the Territory of Wisconsin was created, including the region west of the Mississippi. George W. Jones was elected the territorial delegate in the congress from Michigan in 1835; and, he was elected similarly from Wisconsin in 1837. He fathered the bill to set Iowa off as a territory in 1838; and nearly everybody has heard the story of the struggle to get that bill enacted into law. 
In February of 1838, W. W. Chapman, once briefly editor of the Dubuque Visitor, and then United States district attorney, located in Burlington, announced his candidacy for the congressional office. When Iowa became a territory, Chapman repeated his announcement for the new territory. This rather irked Jones, who had his own ideas on the subject, but who had fallen temporarily under a political cloud by his implication in the famous Graves-Cilley duel. Jones wanted to designate the Democratic candidate, however; and he had picked Peter H. Engle, a young lawyer who had settled in Dubuque before 1836. Engle announced his candidacy. Thomas S. Wilson was on the point of doing so when he learned that he had been appointed to the supreme court of the territory. David Rorer of Burlington and B. F. Wallace of Mt. Pleasant, a brother of W. H. Wallace, already noted, got into the race. Chapman, Rorer and Wallace campaigned a good deal together, making their last stand in Davenport on the Saturday before election. Here Rorer stole Chapman's one speech, which he had heard so often that he knew it by heart. Chapman congratulated Rorer on the best speech that he had made during the campaign, and Rorer retorted that "it was the damnedest poorest speech he had made." A few days before Engle had fallen off his horse crossing the Wapsipinicon. An Indian had pulled him out, but Engle had to stay indoors temporarily with a resultant cold. The rumor got abroad that he drowned, and the other candidates did nothing to refute the rumor. It cost Engle votes, and Chapman was elected by a plurality of thirty-six, the first congressional delegate from Iowa. When the returns were all in a fifth candidate appeared in the running. The original Iowa territory ran north of its present boundary, went in a sort of triangular form to take in a part of the present Minnesota, including Fort Snelling and St. Paul, then known as St. Peter's, originally called Pigseye. Major Lawrence Taliaferro received 
thirty votes up there. He was the man from whom Dr. John Emerson bought Hannah, the wife of Dred Scott.

Chapman was a Virginian who settled in Burlington in 1835. He had held several appointive offices. His term in congress was an active one, but he was not strongly partisan; and in 1840 he realized that he faced a purge, and did not run again. He was succeeded by $\mathrm{A}$. C. Dodge, who continued as delegate in congress until Iowa became a state. In 1847 Chapman was taken with the frontier fever again and he started across the plains to Oregon. He soon was in the legislature of that territory, became an influential citizen, and was one of the founders of the Portland Oregonian, which still thrives out there. He died in 1902.

After his defeat in the 1838 campaign, Engle went to St. Louis, where he attained high professional standing and a place on the bench.

\section{IOWAN'S RELATION WITH LINCOLN}

Prolonged mention of Samuel J. Kirkwoood, governor twice, United States senator twice, secretary of The Interior, is omitted, as he didn't move to Iowa until 1855. Similarly we are passing over Lincoln's most important Iowa appointee, Samuel F. Miller, of Keokuk, justice of the supreme court who came from Kentucky in 1850. Lincoln gave some attention either favorably or unfavorably to other Iowans whose friends proposed them to his consideration.

Fitz Henry Warren of Burlington was on his slate for a cabinet appointment, but was passed over. Warren was a leader in the formation of the Republican party in Iowa, but he never got very far in office holding. He came from Massachusetts to Burlington in 1847. In 1849 he was appointed by President Taylor whom he had helped to nominate in the 1848 voting convention as a delegate from Iowa, as assistant postmaster general. He fell out with President Fillmore a few months later over the 
issue of the Fugitive Slave law and resigned. He had a way of falling out with people easily which did not help his political career. In 1855 he was beaten for United States senator by James Harlan. In 1861 Lincoln offered him his old role in the post office department, but he declined and went instead to New York as an editorial writer for Horace Greeley on The Tribune. He didn't stay long at that; but resigned and entered the Union army where he became a brigadier general. In 1863 he was beaten for the Republican nomination for governor of Iowa by General William M. Stone. After the war he got an election to the state senate; and in 1867 President Johnson appointed him Minister to the Republic of Guatamala. After his return from that office he returned to Massachusetts where he died in 1878.

When Warren turned down Lincoln's suggestion of the post office department the president appointed John A. Kasson of Des Moines who came to Iowa in 1857 and began a brilliant career, including six terms in congress, and United States minister at Madrid, Vienna, and Berlin.

Another of Lincoln's appointees was Alvin D. Saunders as governor of the Territory of Nebraska. Like so many other leaders in early Iowa, Saunders was a Blue Grass product, having been born in Kentucky in 1817. The family moved to Illinois in 1829, in that trek that took the Lincolns to that state; then they moved again to the new settlement of Mount Pleasant in 1836. Saunders had a common school education which was very common in those days. He engaged in mercantile business; read law but never practiced it; was postmaster at Mount Pleasant seven years. He was a member of the Constitutional Convention of 1846; of the state senate in 1854-56, and 58-60. He was a member of the first Republican convention in Iowa City February 22, 1855, of the Republican national convention in 1860 . The appointment as governor of Nebraska territory came in 1861 and he occupied that office till 1867. He remained in Omaha and was elected 
United States senator from Nebraska, served one term, 1877 to 1883 . He died in Nebraska in 1899.

Saunder's daughter Mary married in 1884 Russell B. Harrison, son of Benjamin Harrison, a senator from Indiana, who was elected president in 1888. During the Harrison regime in the White House the Russell Harrisons resided there also. Mary Saunders Harrison and Mary Harrison McKee (mother of "Baby McKee") carried on the social conventions of the place for their invalid mother. The papers of November 30,1944 , carried the announcement of Mrs. Russell Harrison's death in Washington at the age of 84 .

Lincoln made one other important designation from Iowa in the person of James Harlan as secretary of the Interior. Harlan was born in Illinois in 1820 . The family reversed the usual motion and moved east to Indiana where James grew up. He was graduated from what is now DePauw University in 1845; and in that same year came to Iowa City as the president of the incipient Iowa City College which the Methodists were trying to establish. It never got much beyond the incipient stage, and finally was merged with Cornell College in Mt. Vernon. Harlan read law; ran for superintendent of public instruction as a Whig and always felt that the Democrats juggled him out of the election. He declined the Whig nomination for governor in 1850 , as technically he was too young according to the constitution of the state. In 1853 he became president of Iowa Wesleyan College at Mount Pleasant. In 1855 he was elected United States senator to succeed Senator Dodge; the Democrats had blown up in the 1854 election. After his reelection to second term, Lincoln appointed him as secretary of the Interior. The president was dead before Harlan took office. He served under Johnson until July 1866, when his lack of sympathy with Johnson's policies caused him to resign. The next year he was again elected to the senate and served one term. He was presiding judge of 
Court of Commissions on the Alabama Claims from 1882 to 1899. Harlan died in 1899. His daughter Mary became Mrs. Robert T. Lincoln.

\section{OTHER ABLe Men Honored Iowa}

Nor does all this exhaust the roll call. In Bloomington was Ralph F. Lowe, an Ohioan, who came to Iowa in that year, 1838. He was to become governor twenty years later, and chief justice of the Supreme Court. There were the brothers Shepherd Leffler, and Isaac Leffler, born near Wheeling, moved to Iowa in 1835, and settled in Burlington. Isaac had served in the congress from Virginia. Shepherd was to become one of the first representatives in the congress from Iowa serving three terms, besides many other positions with which he was entrusted. He was twenty-five years his brother's junior. In 1875 he was defeated by Samuel J. Kirkwood for governor. There was Francis Springer who came from Maine to Iowa in 1838, and settled in Wapello. He was a big man in Louisa county. There was Gideon S. Bailey, a Kentuckian, who came in 1837, and settled in Van Buren county, where he was a political leader for many years. There was Edward Johnstone, six feet six inches tall, of fine physique and of majestic appearance, a Pennsylvanian who became a Lee county leader. There was Stephen Whicher, the tall, slim, eccentric native of Vermont who had the blood of the Emersons in his veins. He became a talented lawyer in Muscatine.

In Jackson county was another Vermonter who came to Iowa in 1836, by way of Ohio, where he had engaged briefly in the stage line business. He settled at Andrew, and again engaged in stages, with contracts for carrying the mails. In 1838, at the age of thirty-two, he had not been heard of yet politically. In 1846 he became the first governor of the State of Iowa. His name was Ansel Briggs. There was Brigg's Whig opponent in the campaign of 1846, Thomas McKnight of Dubuque, a Vir- 
ginian by birth, who ran again in 1847 for congress, and was defeated again, this time by S. C. Hastings.

In Scott county was G. C. R. Mitchell, a native of Tennessee, who came in 1835 , before there was any Iowa, any Scott county, or any Davenport. He took "squatter's rights," lived in a cabin near the present junction of Sixth and Marquette streets in Davenport. The next year he opened a law office in the new settlement. Mitchell served in the house of the Sixth Territorial legislature; in 1846 he was nominated for congress but was defeated; later that year he received enough support from Whig members of the First General Assembly for United States senator to tie up that election in a knot so far that session of the legislature was concerned. In 1857 he became district judge; but by that time he was a Democrat. He left the Whig party in the centrifugal processes which blew "The opposition" to pieces in the fifties.

James Grant was another Scott county leader, who came from North Carolina in 1838. He had stopped over in Chicago from 1834 to practice law in that struggling village. He was a member of the house in the Fourth Iowa Territorial legislature; a member of the Constitutional Conventions of 1844 and 1846 ; the first district judge in the new judicial district set up by the First General Assembly. In 1852 he was in the house of the Fourth General Assembly, where he was made speaker. Grant might have had higher political distinction, but he preferred to be a consultant in political matters rather than an office holder.

Then, there were the Cooks, Ebenezer and John P., brothers who came from New York with two other brothers, their father, and a sister (Mrs. William Van Tuyl) in 1836. Ebenezer soon attained prominence in law and politics, and later in banking and in railroad promotion. He sat in the Constitutional Convention of 1844 as a Whig and he held many local offices. In the Fourth General Assembly he was a candidate for the United States 
senate, being barely beaten by James Harlan. John P. Cook was in the territorial council in the Fifth and Sixth sessions, and in the senate of the Second and Third General Assemblies. At that time he was a resident of Tipton. He removed to Davenport, from which city he was elected to congress in 1852. He declined to run again. Like Mitchell, he began as a Whig; but in the break up of that party Cook became a Democrat, which left him in a minority party. Two of his great grandsons are present members of the Scott county bar.

There was also Charles Weston, who seems to have been quite forgotten. He was one of the batch of twenty young lawyers who were admitted to practice by the Supreme Court at its first session in November, 1838. Weston was born in Washington county, New York, northeast of Albany, in 1811. He had his later education in the Rensselaer Institute, after which he read law in his father's office and was admitted to the New York bar in 1836. The next year he started west and reached the Mississippi in December. He crossed the river to Burlington on a ferry boat which cruised among a mass of pieces of ice, and Weston nearly lost his life in the trip. Finally getting across, he stumbled along a dark road to a hotel to dry out and get warm, where he met a young fellow dressed in rough frontier clothes and with a head of unruly hair that would not stay combed, who had recently come to the Blackhawk Purchase. His name was Grimes, from New Hampshire. Weston started practice in Burlington. He was one of the few men who remained friends with William B. Conway, the territorial secretary, and was with Conway when he died in November of 1839 . After Conway died Governor Lucas appointed Weston fiscal agent for the territory, and acting secretary until the president designated James Clarke. In 1839 he was appointed United States attorney for the territory, and served until 1843. Some books say that he came to Davenport in 1840 ; but in the list of attorneys admitted by 
the supreme court in November, 1838, Weston and Conway are listed as from this town. At any rate he came, took up a claim and tried farming. That did not pay, and he moved into town and opened his law office. He was elected mayor in 1851, and county judge in 1857 . Urbane, genial, classically educated, fond of books, Judge Weston was a kindly, old-fashioned gentleman, an eminent citizen of his little city.

A hundred years have come and gone. They have woven a fabric of history that none could foresee in 1846 . Into that history have gone a thousand unseen influences from as many sources; but none of them has been stronger than that of the young men who came to the Blackhawk Purchase in the beginning, and with ploughshare, axe, saw, wheel, and book, wove the first threads into the mystery called history-the history of another state in the unique story of America.

\section{References :}

Iowa, Its History and Its Foremost Citizens, Brigham

History of Iowa, Gue

History of The People of Iowa, Harlan

Recollections and Sketches, Stiles

Iowa Through The Years, Cole

Biographical Directory of The American Congress

Dictionary of American Biography

Various County Histories, including Davenport and Scott County. Downer

Lincoln and The Patronage, Carmen and Luthin

Various copies of ANNALS OF Iow and Journal of History and Politics 1

\section{PRIMARY ELECTIONS LONG AGO}

The Democrats of St. Louis in mass meeting assembled adopted a resolution on the 9th of January in favor of the abolishing of conventions for nominating candidates for office and adopting the primary system as a substitute. The resolution is said to have been adopted unanimously. -Dubuque Herald, Jan. 21, 1854. 
Copyright of Annals of Iowa is the property of State of Iowa, by \& through the State Historical Society of Iowa and its content may not be copied or emailed to multiple sites or posted to a listserv without the copyright holder's express written permission. However, users may print, download, or email articles for individual use. 